\title{
Antibacterial Activity of Honey and Erytlaria Acualis against Bacteria Isolated From Burnt Wound Sepsis
}

\author{
V. Kowsalya, \\ M.Sc. Applied Microbiology Department of Microbiology Ethiraj College for Women, Chennai.
}

\begin{abstract}
The growing threat and spread of antibiotic resistance by a wide range of common pathogens has lead to increased investigations into traditional medicinal plants as alternatives. Honey has been used as a medicine since ancient times in many cultures and is still used in 'folk medicine'. It is used widely for healing burnt wounds, but nowadays due to antibiotic resistance organisms honey also took back seat. The present study shows the antibacterial activity of Erytlaria acualis lindau against the bacteria (multidrug resistant bacteria like Pseudomonas aeroginosa, E.coli, and methicillin resistant Staphylococcus aureus) isolated from burnt wound sepsis. Since it was used only for healing and deworming cattle wounds, the present study shows that it can also be used by the humans for the same purpose. Hence it is proved by my grandfather who used the plant extract for his operated wound in leg infected with worms and germs and it also has an efficient healing property. Thus Erytlaria acualis was effective than both honey and antibiotics.
\end{abstract}

Key Words: Antibacterial activity, Antibiotics, Erytlaria acualis, Honey

\subsection{Honey: Overview}

\section{Introduction}

Honey is a sweet food made by bees using nectar from flowers. The variety produced by honey bees (the genus Apis) is one of the most commonly referred to and is the type of honey collected by beekeepers and consumed by humans. Honey produced by other bees and insects has distinctly different properties. Honey bees transform nectar into honey by a process of regurgitation, and store it as a primary food source in wax honey combs inside the beehive. Beekeeping practices encourage overproduction of honey so the excess can be taken from the colony.

Honey gets its sweetness from the monosaccharides fructose and glucose, and has approximately the same relative sweetness as that of granulated sugar. It has attractive chemical properties for baking, and a distinctive flavor that leads some people to prefer it over sugar and other sweeteners. Most microorganisms do not grow in honey because of its low water activity of 0.6.

However, honey sometimes contains dormant endospores of the bacterium Clostridium botulinum, which can be dangerous to infants, as the endospores can transform into Toxin-producing bacteria in the infant's immature intestinal tract, leading to illness and even death. The study of pollens and spores in raw honey (melissopalynology) determines floral sources of honey. As bees carry an electrostatic charge, and can attract other particles, the same techniques of melissopalynology can be used in area like environmental studies of radioactive particles, dust or particular pollution.

\subsubsection{Historical Review of Honey}

Before the advent of antibiotics, it was not unusual for an experienced medical professional to even slather honey on a wound to prevent infection and hasten healing. Honey has been used as a folklore medicine for many different purposes: as a laxative, as a natural cure for diarrhea and upset stomach, for coughs and sore throats. Honey has been known for its healing properties for thousands of years - the Ancient Greeks used it, and so have many other peoples through the ages. Even up to the Second World War, honey was being used for its antibacterial properties in treating wounds. But with the advent of penicillin and other antibiotic drugs in the twentieth century, honey's medicinal qualities have taken a back seat. Treatment with honey is called Apitherapy, which includes replenishing energy, enhancing physical stamina and improving immune systems.

Only a couple of centuries ago man came to know that honey comes from the belly of the bee. This fact was mentioned in the QUR'AN 1,400 years ago in the following verse: "And thy Lord taught the Bee to build its cells in hills, on trees, and in (men's) habitations; There issues From within their bodies A drink of varying colours, Wherein is healing for men.:quot; [AL-QUR'AN 16:68-69]

Ayurveda explains another special quality of honey. Honey is called as "Yogavahi". The substance which has a quality of penetrating the deepest tissue is called as Yogavahi. When honey is used with other herbal preparations it enhances the medicinal qualities of those preparations and also helps them to reachthe deeper tissues.

\subsubsection{The Contents of Honey}

Honey contains the following ingredients 
- Sugars like fructose, glucose, sucrose, maltose, lactose and other disaccharides and trisaccharides

- Proteins, fats, vitamins, minerals, enzymes and amino acids

- Volatile aromatic substances.

- Ashes and water etc.

Various ingredients of honey have helped it to become not only a sweet liquid but also a natural product with high nutritional and medicinal value. The medicinal quality, taste, texture, color, aroma of honey differs according to the geographical area and the species of plants from which it has been collected.

\subsubsection{Therapeutic Uses Of Honey (Table:1.1.3.1)}

\begin{tabular}{|c|c|}
\hline AILMENT & HOW TO USE \\
\hline Arthritis & $\begin{array}{l}\text { Slow massage of honey paste made of one part of honey with two parts } \\
\text { of lukewarm water and a small teaspoon of cinnamon powder, on the } \\
\text { affected area of the body, recedes the pain within a minute or two. Even } \\
\text { chronic arthritis can be cured by consumption of one cup of hot water } \\
\text { with two spoons of honey and one small teaspoon of cinnamon powder } \\
\text { by arthritis patients in the morning and night every day. }\end{array}$ \\
\hline $\begin{array}{l}\text { Bladder } \\
\text { infections }\end{array}$ & $\begin{array}{l}\text { Drinking two tablespoons of cinnamon powder and one teaspoon of } \\
\text { honey in a glass of lukewarm water destroys the germs of the bladder. }\end{array}$ \\
\hline Toothache & $\begin{array}{l}\text { Application of a paste of one teaspoon of cinnamon powder and five } \\
\text { teaspoons of honey on the aching tooth be done } 3 \text { times a day cures the } \\
\text { toothache within a few days }\end{array}$ \\
\hline $\begin{array}{l}\text { Heart } \\
\text { diseases }\end{array}$ & $\begin{array}{l}\text { A paste of honey and cinnamon powder applied on bread or chapatti } \\
\text { instead of jelly and jam and eaten regularly for breakfast reduces the } \\
\text { cholesterol in the arteries and saves the patient from heart attack. } \\
\text { Regular use of the above process relieves loss of breath and strengthens } \\
\text { the heartbeat. }\end{array}$ \\
\hline $\begin{array}{l}\text { Immune } \\
\text { system }\end{array}$ & $\begin{array}{l}\text { Daily use of honey and cinnamon powder strengthens the immune } \\
\text { system and protects the body from bacterial and viral attacks. Scientists } \\
\text { have found that honey has various vitamins and iron in large amounts. } \\
\text { Constant use of honey strengthens the white blood corpuscles to fight } \\
\text { bacterial and viral diseases. }\end{array}$ \\
\hline Longevity & $\begin{array}{l}\text { Tea made with honey and cinnamon powder, when taken regularly } \\
\text { arrests the ravages of old age. Mixture of } 4 \text { spoons of honey, } 1 \text { spoon of } \\
\text { cinnamon powder and } 3 \text { cups of water and boil to make like tea when } \\
\text { drunk } 1 / 4 \text { cup, } 3 \text { to } 4 \text { times a day keeps the skin fresh and soft and } \\
\text { arrests old age. }\end{array}$ \\
\hline Pimples & $\begin{array}{l}\text { Three tablespoons of honey and one teaspoon of cinnamon powder paste } \\
\text { applied on the pimples before sleeping and washing it next morning } \\
\text { with warm water, if done daily for two weeks, removes pimples from } \\
\text { the root. }\end{array}$ \\
\hline $\begin{array}{l}\text { Skin } \\
\text { infections }\end{array}$ & $\begin{array}{l}\text { Eczema, ringworm and all types of skin infections are cured by applying } \\
\text { honey and cinnamon powder in equal parts on the affected parts. }\end{array}$ \\
\hline Cancer & $\begin{array}{l}\text { Patients suffering from advanced cancer of stomach and bones should } \\
\text { take, on a daily basis, one tablespoon of honey with one teaspoon of } \\
\text { cinnamon powder for one month } 3 \text { times a day. }\end{array}$ \\
\hline $\begin{array}{l}\text { Digestive } \\
\text { system }\end{array}$ & $\begin{array}{l}\text { Honey is said to improve food assimilation and to be useful for chronic } \\
\text { and infective intestinal problems such as constipation, duodenal ulcers } \\
\text { and liver disturbances. }\end{array}$ \\
\hline $\begin{array}{l}\text { Respiratory } \\
\text { system }\end{array}$ & $\begin{array}{l}\text { In temperate climates and places with considerable temperature } \\
\text { fluctuations, honey is a well-known remedy for colds and mouth, throat } \\
\text { or bronchial irritations and infections. The benefits, apart from } \\
\text { antibacterial effects, are assumed to relate to the soothing and relaxing } \\
\text { effect of fructose. }\end{array}$ \\
\hline
\end{tabular}




\begin{tabular}{|l|l|}
\hline AILMENT & \multicolumn{1}{|c|}{ HOW TO USE } \\
\hline $\begin{array}{l}\text { Skinand } \\
\text { wound } \\
\text { healing }\end{array}$ & $\begin{array}{l}\text { Honey is used in moisturizing and nourishing cosmetic creams, but also } \\
\text { in pharmaceutical preparations applied directly on open wounds and } \\
\text { burns. If applied immediately, honey reduces blistering of burns and } \\
\text { speeds regeneration of new tissue. It helps against infections, promotes } \\
\text { tissue regeneration, and reduces scarring also in its pure, unprocessed } \\
\text { form.A cream, applied three times per day and prepared from equal } \\
\text { parts of honey, rye flour and olive oil, has been successfully used on } \\
\text { many sores and open wounds. }\end{array}$ \\
\hline $\begin{array}{l}\text { Eye } \\
\text { disorders }\end{array}$ & $\begin{array}{l}\text { Honey reduces and cures eye cataracts, cures conjunctivitis and various } \\
\text { afflictions of the cornea if applied directly into the eye. }\end{array}$ \\
\hline
\end{tabular}

\subsubsection{How Does Honey Work To Treat Infection} properties.

There are many features in the composition of honey that together combine to give it its antimicrobial

TABLE : 1.1.4.1

\begin{tabular}{|l|l|}
\hline Feature & Antimicrobial action \\
\hline High osmolality & $\begin{array}{l}\text { Honey is a saturated or supersaturated solution of sugars that } \\
\text { has strong interaction with water molecules. The lack of 'free' } \\
\text { water inhibits the growth of microorganisms. }\end{array}$ \\
\hline $\begin{array}{l}\text { Hydrogen } \\
\text { peroxide }\end{array}$ & $\begin{array}{l}\text { When honey is diluted by wound exudates, hydrogen } \\
\text { peroxide is produced via a glucose oxidase enzyme reaction. } \\
\text { This is released slowly to provide antibacterial activity but } \\
\text { does not damage tissue. }\end{array}$ \\
\hline $\begin{array}{l}\text { Antibacterial } \\
\text { phytochemicals }\end{array}$ & $\begin{array}{l}\text { Some honeys still have antimicrobial activity even when } \\
\text { hydrogen peroxide activity has been removed. The honey } \\
\text { from Manuka trees (Leptospermum scoparium) has been } \\
\text { found to have high levels of this antibacterial phytochemical. }\end{array}$ \\
\hline
\end{tabular}

In addition to its antimicrobial properties, honey also appears to stimulate lymphocytic and phagocytic activity. These are key body immune responses in the battle against infection.

\subsubsection{Precautions To Be Taken Before Using Honey}

- Honey should not be mixed with hot foods.

- Honey should not be heated.

- Honey should not be consumed when you are working in hot environment where you are exposed to more heat.

- Honey should never be mixed with rain water, hot and spicy foods, and Fermented beverages like whisky, rum, brandy etc, Ghee and mustard.

- Honey includes nectar of various flowers of which some may be poisonous. Poison has hot or ushna qualities. When honey is mixed with hot and spicy foods the poisonous properties get enhanced and cause imbalance of doshas.

\subsection{Erytlaria acualis lindau}

Elytraria acaulis is one such plant that is frequently being used, the leaves decoction of this plant is prescribed in fever, venereal diseases and root is used in mammary tumor, abscesses, pneumonia, and infantile diarrhea as well as traditional medicine for long days. Leaves used for treating wounds infected with worms. Locally in Tamilnadu (Tirunelvelli Dist) it is used as antidiabetic. Elytraria acaulis belongs to the family Acanthaceae is a small shrub, which grows in shady dry places.

It is also used as folklore medicine for curing neck and leg sores for cattles.The plant extract of Elytraria acualis was used by my grandfather for killing worms present in his own leg wound (cancer) and also for healing purpose.

\subsection{Burnt Wound Infection}

1.3.1 Skin: Overview

Skin covers the external surface of the body and is one of the largest organs in surface area and weight. Skin form part of the non-specific host defenses and functions as a mechanical barrier to the surrounding environment and against microbial invasion (Nester et al., 2004,). Injuries to the skin (cuts, 
punctures, burns, bites etc.) provide an entry route for pathogens to infect the skin and underlying tissues. The skin serves many functions and externally it often defines our emotional well being through appearance.

The skin contains its own population of beneficial commensal bacteria that resides on the skin surface. Diptheriods, Staphylococcus spp. (coagulase negative), Micrococcus spp., Bacillus spp. \& fungi form part of the normal microbial population found on the skin surface (Nester et al., 2004; and Packham, 1998). Normal skin flora has a protective function by competitively excluding harmful microorganisms. Many microorganisms (normal flora) in the correct place are beneficial to humans; however the same microorganism may be harmful, even deadly in the wrong place (Packham, 1998).

Staphylococcus epidermidis, a normal commensal of the skin, may have fatal consequences if it breaches the skin integrity and enters the blood circulation. Normal skin flora in combination with regular maintenance of skin hygiene may limit the colonization of harmful pathogens on the skin surface. According to Packham, (1998) maintenance of the skin in a good condition should employ the removal of pathogenic microorganisms without affecting the normal flora. Excessive or misuse of some germicidal cleansers and soaps may deplete the commensal microorganisms and select bacterial resistance (Levy, 1998). The depletion of normal skin flora and loss of natural skin moisture may facilitate the colonization of harmful microorganisms on the skin surface (Alekshun \& Levy, 2001; Levy, 1998;Packham, 1998).

The skin is composed of two main protective portions overlying the subcutaneous layer mainly:

- Epidermis - superficial, thinner portion composed of layers epithelial cells and embedded keratin.

Contains no blood vessels and regenerates without scar tissue if it's damaged. The body reproduces the protective epidermis every 30 days.

- Dermis - deeper thicker portion composed of tightly woven connective tissue and are responsible for skin elasticity and strength. Contain blood vessels and heal with scar formation (Totora \& Grabowski, 1996).

The severity of skin damage is related to the degree of invasion into the epidermis and dermis layers (Ward \& Saffle, 1995). Skin damage may originate from physical injury such as burns, microbial agents (bacterial, viral, fungal, parasitic) or acombination of the two such as burn wound infections. The skin is a complex organthat is able to resist infection based on its properties and regenerate by healing if tissue damage occurs. Tissue damage resulting from physical agents, microbial agents or a combination of the two may initiate an inflammatory response that is aimed at restoring tissue function (Nester et al., 2004). The process of wound healing is complex and dynamic involving a series of physiological phases. Healing is the final stage of response to tissue injury (Macfarlane et al., 2001).

\subsubsection{Skin Related Infection}

A disruption of the skin integrity forms a favorable site for colonization and infection with microorganisms. Invading microorganisms may originate endogenously from the individual and/or exogenously from the environment and fomites. A failure of wound healing may lead to infection, resulting in experiences of increased trauma and treatment costs (Bowler et al., 2001; O'Dell, 1998).

Skin infections are among the most popular conditions still treated traditionally by using medicinal plants. Especially in the Eastern Cape people to a large extent rely on medicinal plants to cure various ailments, including skin diseases (Matsiliza \&Barker, 2001; Grierson \& Afolayan, 1999).

Intact skin acts as a protective barrier to invading microorganisms and ensures a healthy balance of skin flora. Accidental cuts, abrasions and burns in combination with contaminants may predispose infection if its left untreated (O'Dell, 1998).Diagnosis of infection is primarily based on the presence of clinical signs and symptoms. The topical nature of skin infections allows visible observation and monitoring for progression or regression especially when self-medicating (Kingsley,2001).

The difficulty associated with reaching modern medical facilities for common health issues enhances the reliance on traditional herbal remedies. The reliance on traditional herbal healing methods for treating skin conditions has a deep-rooted history in many cultures (Harsha et al., 2003).

\subsubsection{Wound Infection And Inflammation}

The development of wound infection is not a new phenomenon and is an ongoing problem for many people. Open wounds serve as an entry route for contamination 28 with invading microorganisms. Besides delayed wound healing of infected wounds, it is associated with increased discomfort, hospital stay and health care costs (Kingsley, 2001). Infected wounds scar more severely and are associated with prolonged restoration. The risk of systemic infection and even death is also associated with infected wounds (Ward \& Saffle, 1995).

Infection denotes an inflammatory process caused by disease producing organisms. An inflammatory response is initiated by large quantities of different cell types entering the wound, which is ultimately aimed at restoring homeostasis (Collier,2004). Any agent (microbiologic, physical or chemical in origin) causing cell injury,induces the release of inflammatory mediators (Crowley, 1997). The classic signs characterizing 
inflammation, namely redness, pain, swelling, heat and tenderness are mostly self-limiting and subsides with elimination of the harmful agent (Crowley, 1997).

Virulence and dosage of an invading organism as well as the defence mechanisms of the body has an influence on the outcome of infection. Infection is promoted when the body's defence mechanisms are compromised in combination with highly virulent microorganisms (Crowley, 1997). The outcome of infection provokes a series of local and systemic host responses (Bowler $\boldsymbol{e t}$ al., 2001). Infection is characterized by an enhanced severity of the signs of inflammation such as increased exudates, us and odour (Kingsley, 2001).

A multitude of microbial and host factors are involved in the development of a wound infection. According to Bowler $\boldsymbol{e t}$ al. (2001) the type, size, site, and depth of a wound, the host immune status and the virulence of invading microorganisms are some of the factors influencing the progression to an infected wound state.Prolonged or contaminated operations, smoking, malnutrition and inadequate antibiotic prophylaxis are factors elevating the risk of surgical wound infection (Kingsley, 2001).

Infection not only delays healing but may also leads to tissue necrosis in wounds.The presence of necrotic tissue and large amounts of exudates in wounds encourage microbial proliferation and infection (Kingsley, 2001; Collier, 2004). Unhygienic 29 techniques especially when handling wounds play an important role in predisposing the development of infection (Collier, 2004). According to Collier (2004) microorganisms gain access to a wound in a number of ways:

- self-contamination: patients' skin or gastrointestinal tract

- airborne $\quad$ surrounding air or environment

(e.g. dust, water droplets)

- direct contact : equipment or hands of carers

(e.g. septic techniques).

Infection is primarily diagnosed based on the presence of clinical signs and symptoms although microbial culturing is useful in selecting appropriate first line antibiotics (Kingsley, 2001). Early recognition of the signs of infection is important in limiting the effect of infection. According to Bowler et al. (2001) controlling the microbial load of wounds is a vital factor in minimizing infection.

\subsection{Honey The Tastiest Antibiotic}

\section{Review Of Literature}

Honey has been used as a medicine since ancient times in many cultures and is still used in 'folk medicine'. The use of honey as a therapeutic substance has been rediscovered by the medical profession in more recent times, and it is gaining acceptance as an antibacterial agent for the treatment of ulcers and bed sores, and other infections resulting from burns and wounds. In many of the cases in the cited reports, honey was used on infections not responding to standard effective in rapidly clearing up infection and promoting healing. Honey has also been found to be effective in treating bacterial gastroentertis in infants (Molan, Peter C.,2006).

Honey is recognized as an efficacious topical antimicrobial agent in the treatment of burns and wounds (Brudzynski, 2006; Jalali $\boldsymbol{e t}$ al., 2007a). Renewed interest in honey for various therapeutic purposes, including treatment of infected wounds (Jalali et al., 2007), has led to the search for different types of honey with antibacterial activity. The use of honey as therapeutic substance has been rediscovered by medical provincial in more recent times and has been accepted as antibacterial agent for treatment ulcers, bed sore and surface wound infection and surface infections resulting from wounds (Tossoun et al., 1997; Brudzynski, 2006). Also honey has been found to be antioxidant activity (Atrooz et al., 2008) and act as effective in treating bacterial gastroenteritis in infants (Brady et al., 2004) and liver disease (Yoirish, 1977).

The antibacterial activity of honey referred to the endogenous hydrogen peroxide content (Brudzynski, 2006; Mercan et al., 2007), inhibin (Nour, 1988) which acts as antibacterial factor other than $\mathrm{H}_{2} \mathrm{O}_{2}$ (Molan and Russell, 1988). The antibacterial activity of different honey was studied by as Molan (1992), Elbagaury and Rasmy (1993), Al-Somal et al. (1994), Hegazi et al. (2002) and Brady et al. (2004).

Honey is increasingly being used as a dressing for infected wounds (Molan, 1999). Interest in its antibacterial properties has arisen mainly as a result of accounts of its inhibitory action against common woundinfecting species of bacteria (Willix et al, 1992; Cooper and Molan, 1999; Cooper et al, 1999), including methicillin-resistant Staphylococcus aureus (Allen et al, 2000). More general reports of its effectiveness in managing a wide range of wounds (Molan, 1999), particularly where conventional treatments have failed (Dunford et al, 2000), have also contributed to interest in its use.

There is, however, a lack of awareness among clinicians of the wide variations in the antibacterial activity of honey (Molan, 1992), which is often compounded by a failure to use dressing procedures that keep sufficient levels of honey in contact with the wound. In many cases this means that the full potential of the treatment is not realised.

Fifty-nine patients with wounds and ulcers most of which ( 80 per cent) had failed to heal with conventional treatment were treated with unprocessed honey. Fifty-eight cases showed remarkable 
improvement following topical application of honey. One case, later diagnosed as Buruli ulcer, failed to respond. Wounds that were sterile at the outset, remained sterile until healed, while infected wounds and ulcer became sterile within 1 week of topical application of honey. Honey debrided wounds rapidly, replacing sloughs with granulation tissue. It also promoted rapid epithelialization, and absorption of oedema from around the ulcer margins. ( Mr. S. E. E. Efem, 2005)

Both honey and sugar are used with good effect as dressings for wounds and ulcers. The good control of infection is attributed to the high osmolarity, but honey can have additional antibacterial activity because of its content of hydrogen peroxide and unidentified substances from certain floral sources. Manuka honey is known to have a high level of the latter.

Seven major wound-infecting species of bacteria were studied to compare their sensitivity to the nonperoxide antibacterial activity of manuka honey and to a honey in which the antibacterial activity was primarily due to hydrogen peroxide. Honeys with activity in the middle of the normal range were used. A comparison of the median response of the various species of bacteria showed no significant difference between the two types of activity overall, but marked differences between the two types of activity in the rank order of sensitivity of the seven bacterial species. The non-peroxide antibacterial activity of manuka honey at a honey concentration of $1.8 \%(\mathrm{v} / \mathrm{v})$ completely inhibited the growth of Staphylococcus aureus during incubation for $8 \mathrm{~h}$. The growth of all seven species was completely inhibited by both types of honey at concentrations below $11 \%$ (v/v). ( D.J. Willix, P.C. Molan*, C.G. Harfoot ,2008).

The widespread development of antibiotic-resistant bacteria has generated an increasing interest in the use of alternate therapies for the treatment of infected wounds. In 1989, an editorial in the Journal of the Royal Society of Medicine, referring to reports on the successful use of honey in wounds, stated: 'The therapeutic potential of uncontaminated, pure honey is grossly underutilized. This paper examines how the chemical and physical properties of honey may facilitate wound healing and offers guidance on practical issues related to clinical use. ( Molan, Peter C. , 1999)

\subsection{Erytlaria Acualis Lindau}

Elytraria acaulis is a shrub and traditionally used in many countries for the treatment of various diseases and disorders. The aim of the present study was to evaluate the safety of the methanol extract of Elytraria acaulis shrub through acute and sub acute toxicity study in rats.For acute toxicity study 50-2000 $\mathrm{mg} / \mathrm{kg}$ methanol extract of Elytraria acaulis were administered orally and obvious toxic symptoms and mortality was studied up to $72 \mathrm{hrs}$. In sub acute study, effect of multiple weekly dosing of $400 \mathrm{mg} / \mathrm{kg}$ (one-fifth of the maximum tolerated dose) of methanol extract of Elytraria acaulis was investigated in rats for six weeks and the evaluation was done by the studies of haematological parameters, biochemical estimations of hepatorenal parameters, histological observations of the tissue. The extract was found to be well tolerated up to $2 \mathrm{~g} / \mathrm{kg}$ in acute toxicity study. In sub acute toxicity studies it showed no significant alteration on any of the parameters, which was evident by the histological studies. Hence the results suggest that methanol extract of Elytraria acaulis whole plant is quite safe and can be used in the treatment of the chronic diseases without any toxicity (Koshy et al., 2011)

\subsection{Burnt Wound Infection}

Bacterial infection is a frequent and serious infectious complication in burn recipients (Mayhall, 2003 and ; Pandit \& Gore, 1997). Burn wound infection is associated with prolonged healing and the risk of systemic infection (Palmeiri \& Greenhalgh, 2002). Approximately 50 - 75\% of deaths following burns are related to infections (Pandit \& Gore, 1997; and Schwarz, 2001). Resistance to antimicrobial agents and a generalised immune suppression are risk factors that contribute to burn wound colonization and infection (Mayhall, 2003).

In recent years burn injuries have reached epidemic proportions in the United States,mainly targeting children (Palmeiri \& Greenhalgh, 2002). In the United States burn wound infections occur most frequently in children followed by the elderly (Schwarz, 2001). An Australian paediatric hospital reported treating more than 720 new cases annually, with the majority resulting from tea and coffee scalds (McCormack et al., 2003).

Minor burns are extremely common in children and may be attributed to its accidental nature in households (McCormack et al., 2003). According to a surgical 30 consultant in the Nelson Mandela metropole, burns are lethal injuries that may kill children even in the best burn care facilities, based on the degree of surface area involved in relation to their body size (Jones, 2002). In the United States an estimated 2.5 million people sustain burns that require medical attention annually (Mayhall, 2003). Infected burn wounds increases the length of hospital stay and treatment costs (Arslan et al., 1999). Burn wounds resulting in a loss of the protective skin coverage forms a favourable entry route for microbial colonization. Burn injuries facilitates microbial growth in the moist, protein rich avascular eschar that replaces the normal skin barrier (Schwarz, 2001).Burn wounds are normally described based on the percentage involvement of body surface area (\%BSA) 

and the depth of skin injury (first, second or third degree) (Ward \& Saffle, 1995). Burns are classified skin traumas according to the depth of injury in the different skin layers as:

TABLE: 4.3.1

\begin{tabular}{|l|l|l|}
\hline Superficial injury & 1 st degree & $\begin{array}{l}\text { limited to the epidermis with heat, } \\
\text { pain and reddening e.g. sunburns. }\end{array}$ \\
\hline $\begin{array}{l}\text { Partial thickness } \\
\text { injury }\end{array}$ & $\begin{array}{l}\text { 2nd } \\
\text { degree }\end{array}$ & $\begin{array}{l}\text { extend to dermis including extreme } \\
\text { pain and blister formation. }\end{array}$ \\
\hline Full thickness injury & 3rd degree & $\begin{array}{l}\text { extends to the subcutaneous layer } \\
\text { with a leathery appearance. }\end{array}$ \\
\hline
\end{tabular}

Burns are serious injuries that should not be underestimated in terms of immediate attention and management required in alleviating infectious complications. The outcome of burn injuries is multifactorial and may differ from one person to another, depending on the degree of injury and their general health status. Severe burns are complex injuries that require specialized assistance in providing a positive outcome. Awareness of appropriate first-aid for burn injuries is important due to its accidental nature and benefits of alleviating patient discomfort. Immediate cooling of burns using cool running water for $10-30$ minutes are beneficial in reducing pain, swelling and hospitalisation (Skinner et al., 2004; McCormack et al., 2003). Cooling the affected burn area as first-aid should be accompanied by keeping the rest of the 31 body warm to prevent hypothermia, especially in children (Skinner et al., 2004; McCormack et al., 2003).

Some management measures for burn wound infections include removal of necrotic tissue, rational antibiotic therapy, enhancing the immune response and providing adequate nutrition (Bagdonas et al., 2003; Bowler et al., 2001). Successful treatment of burn wounds relies on understanding the spectrum of common pathogens, mechanisms of resistance and infection control procedures (Kanchanapoom \& Khardori, 2002). According to Collier (2004) it is important to treat the patient as a whole and not the infection alone, focussing on a holistic assessment of an individual.

\section{4 .Pathogens Associated With Burn Wound Infection}

The nature of burn wound injury resulting in the disruption of skin integrity allows colonization of microorganisms from various origins that initiate wound infection. Different types of microorganisms may colonize and cause infection in burn wounds, resulting in a polymicrobial wound infection. According to Trengrove et al. (1996) there is an increase chance of failure to heal if four or more bacterial groups are present in the wound.

The burn wound is usually sterile immediately following injury, with different microorganisms colonizing the wound over time (Ugburo et al., 2004; Schwarz, 2001). Aerobic and facultative pathogens such as Staphylococcus aureus, $P$. aeruginosa \& Streptococcus pyogenes are primary causes of infection and delayed healing in wounds (Collier, 2004; Bowler et al., 2001). The normal skin flora that includes Gram-positive Staphylococcus \& Streptococci spp. tends to result in early burn wound infection. At a later stage more predominant Gram-negative bacteria associated with increased exudates and patient discomfort tend to colonize the burn wound (Palmeiri \& Greenhalgh, 2002; Kanchanapoom \& Khardori, 2002). Although wound infections may result from aerobic and anaerobic microorganisms, aerobes are more commonly isolated due to the difficulty associated with the isolation and culturing of anaerobes (Bowler et al., 2001). Previous epidemiological studies that reported on the microbial assessment of infected burn wounds, indicated frequent isolations of the following bacteria from burn wound swabs:

- P. aeruginosa followed by $S$. aureus were reported as the most common microorganisms causing wound infection in burns (Ugburo et al., 2004;Mayhall, 2003).

- Bagdonas et al. (2003) reported S. aureus as the most common infective agent in burn wounds and may often result in toxic shock.

- Studies and surveys on the bacteriology of burns have indicated frequent isolations of $K$. pneumoniae, Proteus spp., Enterococci spp., Acinetobacter spp. \& Candida albicans to name a few (Bagdonas et al., 2003; Pandit \& Gore, 1997).

- Schwarz (2001) reported S. aureus, P. aeruginosa, K. pneumoniae, E. feacalis \& $\quad$ A. baumanii as some of the most frequently isolated organisms from burn wound biopsies.

Microorganisms infecting wounds are associated with different characteristics and virulence factors that aid infection and patient discomfort.The multiplication of some anaerobes and aerobes in wounds, which include Proteus spp., Klebsiella spp. \& Pseudomonas spp.produce uncomfortable situations e.g. a foul smelling odour (Kingsley, 2001). 
The production of potentially destructive virulence factors by pathogens may impair woundhealing. More than $90 \%$ of S. aureus produce specific enzymes that inactivate certain antimicrobial agents, rendering the antimicrobial ineffective for treatment (Bagdonas et al., 2003). The release of different bacterial toxins is associated with delayed healing and toxic shock. It is important to limit the spread and invasion of microorganisms with their potentially destructive virulence factors that cause infection and delay healing.Controlling the microbial load in wound infections may limit the infection and enhance healing.

\subsection{Antibiotic Resistance}

Opportunistic pathogens and nosocomial infections are important causes of infection in burn wounds due to the compromised skin barrier in burn injuries (Bowler et al., 2001). According to the WHO antibiotic resistant bacteria are responsible for up to $60 \%$ of hospital-acquired infections in the United States (World Health Report: press release (http://www.who.int/whr/1996/press1.htm). Bagdonas et al. (2003) reported that resistance is site depended, with the burns and trauma departments reported as some of the most common sites for the emergence of resistance. Antibiotic resistance is considered a global health concern and has been called one of the world's most pressing public health problems (http://www.cdc.gov/drugresistance/community/).

Some of the bacteria are resistant to as many as ten different drugs, raising the concern of a postantibiotic era (http://www.who.int/whr/1996/press1.htm). Current trends suggest that no effective therapies will be available for treating some diseases within the next ten years (http://www.who.int.mediacentre/factsheet/fs194/en/). The rates of some communicable diseases have started to increase again as a result of the rise in antibiotic resistance (Levy, 1998).

Various facets contribute to the occurrence and spread of antimicrobial resistance.The uncontrolled and inappropriate use of antibiotics today, may reduce future effectiveness of the antibiotics. For example individuals chronically medicating acne with antibiotics in a household, raise the concentration of antibiotic resistant bacteria on the skin of family members (Levy, 1998). Antimicrobial soaps and detergents as well as the agricultural use of antibiotics as growth factors, increase the pressure on wild bacteria to evolve resistance (Alekshun \& Levy, 2001; Berkowitz, 1995). Overcrowded and unhygienic conditions as well as international travelling and trading facilitate the spread of antibiotic resistance (http://www.who.int/whr/1996/press1.htm). The increasing misuse of antibiotics has led to an international public health nightmare, with increasing bacterial resistance to many antibiotics that once readily cured bacterial diseases (Levy, 1998). With each passing decade bacteria that defy not only single but also multiple antibiotics have become increasingly common and 37 extremely difficult to control. Resistant nosocomial infections are expensive to control and eradicate (http://www.who.int.mediacentre/factsheet/fs194/en/).

Antibiotic resistance in bacteria results from the acquirement of genes conferring resistance and the use of these acquired mechanisms for expressing resistance to antimicrobial agents. Antibiotics inactivate defenceless bacteria, resulting in the selection and survival of the fittest; antibiotic resistant bacteria (Lewis, 1995).Resistant bacteria have various mechanisms to disable the harmful actions of certain antibiotics, ensuring bacterial survival, such as:

_ production of enzymes that destroy the active antibiotic

_ changing cell wall permeability to antibiotics

- rapid effluence/discharge of antibiotics form the interior of the bacteria and

_ developing structural alteration in the attachment site for antibiotics (Lewis, 1995).

The search for new effective antimicrobial agents may alleviate the difficulties associated with patient outcome and treatment of antibiotic resistant infections. The investigation and discovery of novel effective antimicrobial agents should be accompanied with an appreciation and rational use of current antibiotics. Scientific investigation of traditionally used medicinal plants for antimicrobial properties may serve as effective agents for the treatment of antibiotic resistant infections. Eloff (1998) suggested that antimicrobial agents originating from plants might use a different mechanism to inhibit microorganisms and resistant pathogens. Implementation of simple infection control practices such as hand washing, use of protective clothing and aseptic techniques may limit the spread of resistant microbes, especially in hospitals. The WHO launched a global strategy in 2001 for combating antimicrobial resistance, aimed at slowing the emergence and reducing the spread of resistance (http://www.who.int.mediacentre /factsheet/fs194/en/). Antibiotic resistance is inevitable, but measures such as infection control, development of antimicrobial agents and rational use of effective antimicrobial agents may slow resistance (Lewis, 1995)

In this study, the best antibiotics among the chemical antibiotics, honey and nilakadambai against bacteria isolated from burn sepsis is determined.

\section{Scope And Objectives}

The medicinal properties of honey have been known since ancient times. Ayurveda (Indian medicine) describes honey as the nectar of life and recommends its use in various ailments. There is renewed interest in honey treatment as evidenced by the number of reports appearing in the scientific literature. 
Honey has been useful in the treatment of surgical wounds, burns, and decubitus ulcers, and the antibacterial and antifungal properties of honey have been well documented. Antibacterial properties of honey are the result of the low water activity causing osmosis, chelation of free Iron, its slow release of hydrogen peroxide, high acidity, and the antibacterial activity of methylglyoxal. Nilakadambai is issued as traditional veterinary medicine. It has an efficient healing property and kill the worms present in wounds. It can also be used for human wounds. This study was undertaken in order to determine the minimum inhibitory concentration (MIC) of honey on bacteria isolated from burn wounds.

\section{Objectives:}

- To isolate bacteria from burnt sepsis

- To perform various biochemical and selective tests to identify the species.

- To perform antibiotic sensitivity test using different antibiotics.

- To determine the antibacterial activity of honey and nilakdambai by performing agar well diffusion method.

\section{Materials And Methods}

\subsection{Samples}

The burnt wound sepsis samples was collected from 30 patients.

\subsection{Collection Of Samples}

The sterile swab was introduced deeply enough to obtain a moist specimen and the swab was replaced in the transport media. The sampled swab was taken immediately to the laboratory for processing of the sample. If delayed inoculated in the nutrient broth.

\subsubsection{Honey And Herb}

The honey used was taken from the tree and extracted from the comb immediately. It did not contain any additives and had not been heated. particles.

Fresh leaves were plucked from the plant and it was washed thoroughly with tap water to remove soil

\subsection{Processing Of Samples}

The sampled swab was streaked in nutrient agar medium. It was incubated at $37^{\circ} \mathrm{C}$ for $24 \mathrm{hrs}$. The developed colonies were differentiated based on their colony morphology.

\subsubsection{Prelimnary Test}

\subsubsection{Gram's Staining}

Gram staining technique was first discovered by a Danish physician named Hans Christian gram in 1884. This technique divides bacterial cells into two major groups, gram positive and gram negative bacteria, this makes it an essential tool for clarification and differentiation of microorganisms.

A thin smear was prepared on a clean grease free glass slide. The smear was flooded with crystal violet and allowed to stand for 1 minute. Then the slide was washed with water and then flooded with gram's iodine and left for 1 minute. The stain was drained and decolourised with $95 \%$ ethanol which was then washed with water. The smear was counter stained with saffaranin for 1 minute. The slide was blot dried and examined under microscope.

\subsubsection{Motility}

The hanging drop technique was followed to observe the motility of the bacteria. It is done to check whether the organism is motile or non motile. A clean cover slip was placed with petroleum jelly at the four corners. A microbial suspension was placed over it and inverted with the slide on top producing a hanging drop.

\subsubsection{Inoculation onto Basal Medium}

The culture was streaked on the nutrient agar medium with help of an inoculation loop. The medium was incubated at $37^{\circ} \mathrm{C}$ for $24 \mathrm{hrs}$.

\subsubsection{Inoculation into Selective Medium}

After overnight incubation, the nutrient agar medium was checked for growth. Colony morphology was noted down and the gram's staining and motility was performed again. Based on the colony morphology and the grams staining and motility, culture was inoculated in selective media like Macconkey agar, Blood agar and Eosin methylene blue agar. It was incubated at $37^{\circ} \mathrm{C}$ for $24 \mathrm{hrs}$.

\subsubsection{Biochemical Test}




\subsubsection{Imvic Test \\ 4.3.4.1.1. Indole Production Test}

Tryptophan is an essential aminoacid that can undergo oxidation by the enzymatic activities of some bacteria. Conversion of tryptophan into metabolic end product is mediated by the enzyme tryptophanase.

The presence of indole is detectable by adding Kovac's reagent, which produces a cherry red reagent layer. The colour is produced by the reagent, which is composed of P-dimethyl amino benzaldehyde, butanol and hydrochloric acid. Indole is extracted from a medium into the reagent layer by the acidified butanol component and forms a complex with the P-dimethyl amino benzaldehyde, yielding a cherry red colour (Rosindole dye).

\subsection{Methyl Red Test}

Methyl red is a pH indicator with a range between 6(yellow) and 4.4(red). The $\mathrm{pH}$ at which methyl red detects acid is considerably lower than the $\mathrm{pH}$ of other indicators used in bacteriological culture media. Thus to produce a colour change, the test organism must produce large quantities of acid from the carbohydrate substrate being used. Methyl red test is a quantitative test for the detection of mixed acid production (lactic, formic, acetic and pyruvic acids) from glucose through mixed acid fermentation pathway.

\subsection{Voges Proskauer Test}

This test is to determine the capacity of some organism to ferment carbohydrate with the production of non acidic or neutral end products such as acetyl methyl carbinol or its reaction product 2,3 butylene glycol. These substances can be tested by a colour change.

\subsection{Citrate Utilization Test}

Some microorganism use citrate as the carbon source in absence of glucose or lactose. Citrate is acted upon by the enzyme which produces oxaloacetic acid and acetate. These are then enzymatically converted to pyruvic acid and carbondioxide. During this reaction , the medium becomes alkaline. This is detected by change in colour from green to deep Prussian blue.

\subsubsection{Triple Sugar Iron Agar Test}

TSI test is used to differentiate different group of Enterobacteriaceae according to their ability to ferment lactose, sucrose, glucose and the production of hydrogen sulphide. The fermentation reaction will help to distinguish the enterobacteriaceae from other gram negative intestinal bacteria. The TSI slant contains $1 \%$ each of lactose and sucrose and glucose in a concentration of $0.1 \%$. The phenol red, the acid base indicator is incorporated in the medium to detect carbohydrate fermentation.

\subsubsection{Urease Test}

Urea is a diamide of carbonic acid. Urease, the enzyme produced by the bacteria and fungi, hydrolyses urea and releases ammonia and carbon dioxide. Ammonia reacts in solution to form ammonium carbonate, which is alkaline leading to an increase $\mathrm{pH}$ of the medium. Phenol red is incorporated in the medium changes its colour from yellow to red, thus indicating the presence of activity .

\subsubsection{Nitrate Test}

Certain bacteria use nitrate $\left(\mathrm{NO}_{3}\right)$ in place of oxygen as an external terminal electron acceptor.In the beginning, nitrate can easily be reduced to nitrate. In case of aerobic bacteria, oxygen is first used to prevent nitrate reduction and then utilize nitrate. The nitrite may further give rise to nitrogen, ammonia, nitrogen oxide $\left(\mathrm{N}_{2} \mathrm{O}\right)$. The presence of nitrites in the medium is detected by the addition of alpha naphthylamine and sulfanilic acid, with the formation of a red diazonium dye, P sulfo benzene-azo-alpha-napthylamine .this gives red colour to the positive reaction.

\subsubsection{Catalase Test}

Most of aerobes and facultative anaerobes have the characteristic of showing catalase activity. Actually, these organisms utilize oxygen to produce hydrogen peroxide. The hydrogen peroxide is toxic to their enzyme system. Hence, these organisms produce an enzyme called catalase, which converts the hydrogen peroxide to water and oxygen. It is also that the reason of not surviving anaerobes in the presence of oxygen is $\mathrm{H}_{2} \mathrm{O}_{2}$ production and the absence of enzyme catalase.

\subsubsection{Oxidase Test}

To differentiate certain group of bacteria, oxidase activity is one of the tests. Certain bacteria are oxidase negative as found in most of the members of the family Enterobacteriace, while Pseudomonas shows 
oxidase positive. To perform the test, a dye p-aminodimethylanilinoxalate or dimethyl-p-phenylenediamine hydrochloride is used. It donates the electron to cytochrome $\mathrm{C}$, becomes oxidized, and produces a colour.

\subsection{Identification of The Pathogen}

Based on the results obtained in the biochemical tests and the colony morphology on the selective media, the pathogen was identified. Pure cultures of the particular pathogen were then maintained in either nutrient agar slants or nutrient agar plates for antimicrobial testing.

\subsubsection{PLANT EXTRACTION}

An extraction method adapted from Eloff (2000) was employed using approximately $5 \mathrm{~g}$ of freshly processed plant leaf. Three different steps performed to obtain the plant extract supernatants The extraction procedure was performed as follows with the fresh plant material:

\section{DAY 1 - Plant extraction}

- Methanol, ethanol and sterile distilled water (aqueous) were chosen as the

extraction solvents (extractants) for extracting different compounds from the

plant material, respectively.

- Weighed plant material and $5 \mathrm{ml}$ of each solvent were placed in screw cap

tubes, respectively and shaken vigorously for $5 \mathrm{~min}$.

- Centrifugation of different extracts in tubes for $5 \mathrm{~min}$ separated the supernatant from the plant material for each extract.

- Supernatant of each plant extract was transferred into pre-weighed beakers

- Procedure was repeated twice more for re-extracting the remaining plant material with additions of $5 \mathrm{ml}$ solvent, respectively.

- The pre-weighed beakers containing the plant extract supernatants were allowed to dry completely to obtain a solvent-free dried extract residue.

- Methanol and acetone plant extract supernatants were subjected to overnight drying under airflow in a fume cupboard.

- Incomplete drying of the aqueous plant extract supernatants prompted alternative drying at $37{ }^{\circ} \mathrm{C}$ overnight.

\section{DAY 2 - Plant extraction}

- Dried beakers were reweighed and calculated extract residues resuspended in $0.5 \mathrm{ml}$ DMSO [Merck].

- Plant extract concentrations varied between the different plants and solvents used for extraction.

- Prior to assaying, a $1.25 \%$ extract solution was made using the stock DMSO extracts and sterile distilled water.

\subsubsection{Antibacterial Sensitivity Testing}

\subsubsection{Disc Diffusion Test}

The chemotherapeutic agents are known as antibiotics. Each antibiotics do possess different antimicrobial activities with respect to different microorganisms. Some of them have short spectrum some with broad spectrum against wide range of microbes. The diameter of zone of inhibition, resulting from diffusion of drug into the medium ( Muller Hinton agar)

- The sterile swab was taken and moisten with broth (culture) and it was pressed against the sides of tubes to remove excess fluid and was swabbed evenly throughout the medium.

- The surface of the plate was allowed to dry.

- Using sterile forceps, antimicrobial discs were placed with some distance and pressed slightly.

- The plates were inverted and incubated at $37^{\circ} \mathrm{C}$ for $24 \mathrm{hrs}$.

- Control were also swabbed and placed with discs and incubated.

\subsubsection{Agar Well Diffusion Method}

- Muller Hinton agar plates were prepared and the surface of the plate was allowed to dry.

- The culture was taken in a sterile swab and swabbed evenly throughout the medium.

- The wells were punched using well borer of diameter around $3 \mathrm{~mm}$ in a dried MHA plates.

- The honey under the concentration of 1:2,1:4 and the crude extract was added to the wells and the plant extracts prepared using three different solvents were also added in different plates.

- The plates were incubated at $37^{\circ} \mathrm{C}$ for $24 \mathrm{hrs}$ in upright position. 


\section{Results And Discussion}

Table 5.1. Isolates Obtained From Burnt Wound Samples

\begin{tabular}{|c|c|c|}
\hline S.No. & NUMBER OF STRAINS & NAME OF STRAINS \\
\hline 1. & $\begin{array}{l}\text { Strain } \\
1,7,11,12,15,16,18,19,27,28,29\end{array}$ & Pseudomonas aeruginosa \\
\hline 2. & Strain 4,9,17,20-23,25 & Staphylococcus aureus \\
\hline 3. & Strain 3 & Staphylococcus saprophyticus \\
\hline 4. & Strain 5,26 & Klebsiella pneumonia \\
\hline 5. & Strain $2,10,13,14,30$ & Escherichia coli \\
\hline 6. & Strain 6, 8, 24 & Proteus mirabilis \\
\hline & \multicolumn{2}{|c|}{ Total no. of strains $=30$} \\
\hline
\end{tabular}

Table 5.2. Key: Antibiotics

\begin{tabular}{|c|c|c|}
\hline S.No & Symbol & Antibiotics \\
\hline 1 & $\mathrm{~A}$ & Ampicillin \\
\hline 2 & $\mathrm{Ak}$ & Amikacin \\
\hline 3 & $\mathrm{Am}$ & Amoxycillin \\
\hline 4 & $\mathrm{C}$ & Chloromphenicol \\
\hline 5 & $\mathrm{CD}$ & Clindamycin \\
\hline 6 & $\mathrm{CI}$ & Ceftriazone \\
\hline 7 & $\mathrm{CZ}$ & Cefazolin \\
\hline 8 & $\mathrm{E}$ & Erythromycin \\
\hline 9 & $\mathrm{G}$ & Gentamycin \\
\hline 10 & $\mathrm{~K}$ & Kanamycin \\
\hline 11 & $\mathrm{LZ}$ & Linezolid \\
\hline 12 & $\mathrm{M}$ & Methicillin \\
\hline 13 & NA & Nalidixic acid \\
\hline 14 & NV & Novobiocin \\
\hline 15 & NX & Norfloxacin \\
\hline 16 & $\mathrm{OF}$ & Ofloxacin \\
\hline 17 & $\mathrm{P}$ & Penicillin \\
\hline 18 & $\mathrm{~S}$ & Streptomycin \\
\hline 19 & $\mathrm{~T}$ & Tetracyclin \\
\hline 20 & $\mathrm{~V}$ & Vancomycin \\
\hline
\end{tabular}

Table 5.3. Antibacterial Activity Of Honey

\begin{tabular}{|l|l|c|l|l|l|}
\hline S.N & \multicolumn{1}{|c|}{ ORGANISM } & \multirow{2}{*}{$\begin{array}{l}\text { NO.OF } \\
\text { O. }\end{array}$} & & \multicolumn{3}{|c|}{ CONCENTRATION } \\
\cline { 4 - 7 } & & 11 & + & + & - \\
\hline 1. & $\begin{array}{l}\text { Pseudomonas } \\
\text { aeruginosa }\end{array}$ & & & & $\mathbf{1}$ \\
\hline 2. & Staphylococcus aureus & 8 & + & + & - \\
\hline 3. & $\begin{array}{l}\text { Staphylococcus } \\
\text { saprophyticus }\end{array}$ & 1 & - & + & - \\
\hline 4. & Klebsiella pneumonia & 2 & - & + & - \\
\hline 5. & Escherichia coli & 5 & + & + & - \\
\hline 6. & Proteus mirabilis & 3 & - & + & - \\
\hline
\end{tabular}

KEY :

$"+"=$ No growth - Activity present

" - " = Growth - No activity present 
Table 5.4. Antibacterial Activity Of Honey

\begin{tabular}{|c|c|c|c|c|c|}
\hline \multirow{2}{*}{$\begin{array}{l}\text { S. } \\
\text { No } \\
\text {. }\end{array}$} & \multirow[t]{2}{*}{ ORGANISM } & \multirow[t]{2}{*}{$\begin{array}{l}\text { NO.OF } \\
\text { STRAINS }\end{array}$} & \multicolumn{3}{|c|}{ CONCENTRATION } \\
\hline & & & $\begin{array}{l}\text { CRUD } \\
\mathrm{E}\end{array}$ & $1: 2$ & $1: 4$ \\
\hline 1. & $\begin{array}{l}\text { Pseudomonas } \\
\text { aeruginosa }\end{array}$ & 11 & + & + & - \\
\hline 2. & Staphylococcus aureus & 8 & + & + & - \\
\hline 3. & $\begin{array}{l}\text { Staphylococcus } \\
\text { saprophyticus }\end{array}$ & 1 & - & + & - \\
\hline 4. & Klebsiella pneumonia & 2 & - & + & - \\
\hline 5. & Escherichia coli & 5 & + & + & - \\
\hline 6. & Proteus mirabilis & 3 & - & + & - \\
\hline
\end{tabular}

KEY :

$"+"=$ No growth - Activity present

" - " = Growth - No activity present

Table 5.5. Antibacterial Activity Of Erytlaria Acualis

\begin{tabular}{|l|l|l|l|l|l|}
\hline \multirow{2}{*}{$\begin{array}{l}\text { S.N } \\
\text { o. }\end{array}$} & \multicolumn{1}{|c|}{ ORGANISM } & $\begin{array}{l}\text { NO.OF } \\
\text { STRAIN }\end{array}$ & \multicolumn{3}{|c|}{ PLANT EXTRACT $\quad(5 \mu \mathrm{I} \quad /$} \\
\cline { 4 - 6 } & & $\begin{array}{l}\text { ETHAN } \\
\text { OL }\end{array}$ & $\begin{array}{l}\text { METHAN } \\
\text { OL }\end{array}$ & $\begin{array}{l}\text { DIS.WAT } \\
\text { ER }\end{array}$ \\
\hline 1. & $\begin{array}{l}\text { Pseudomonas } \\
\text { aeruginosa }\end{array}$ & 11 & + & - & - \\
\hline 2. & Staphylococcus aureus & 8 & + & - & - \\
\hline 3. & $\begin{array}{l}\text { Staphylococcus } \\
\text { saprophyticus }\end{array}$ & 1 & + & - & - \\
\hline 4. & Klebsiella pneumonia & 2 & + & - & - \\
\hline 5. & Escherichia coli & 5 & + & - & - \\
\hline 6. & Proteus mirabilis & 3 & + & - & - \\
\hline
\end{tabular}

KEY :

$"+"=$ No growth - Activity present

" - " = Growth - No activity present

Chart 5.1. Prevalence Of Different Bacteria In Wound

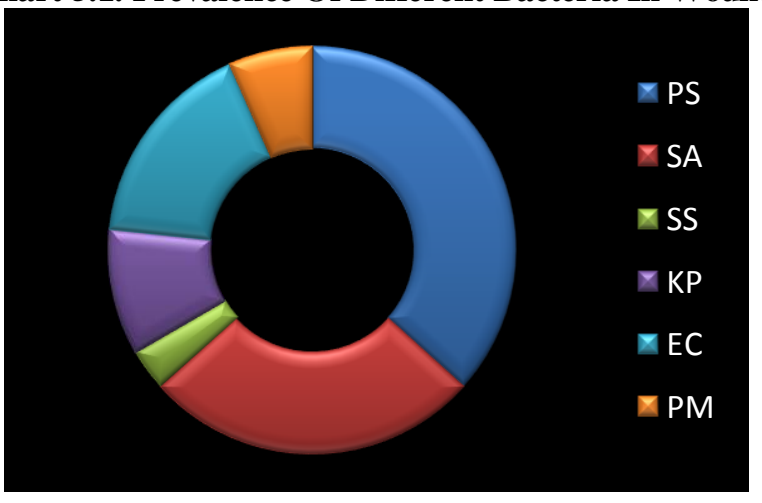

KEY:

P.A $\rightarrow$ Pseudomonas aeruginosa

$\mathrm{S} . \mathrm{A} \rightarrow$ Staphylococcus aureus

$\mathrm{S} . \mathrm{S} \rightarrow \quad$ Staphylococcus saprophyticus

$\mathrm{K} . \mathrm{P} \rightarrow \quad$ Klebsiella pneumonia

E.C $\rightarrow$ Escherichia coli

$\mathrm{P} . \mathrm{M} \rightarrow$ Proteus mirabilis 
Chart 5.2.Comparitive Study Of The Honey And Erytlaria Acualis Activity

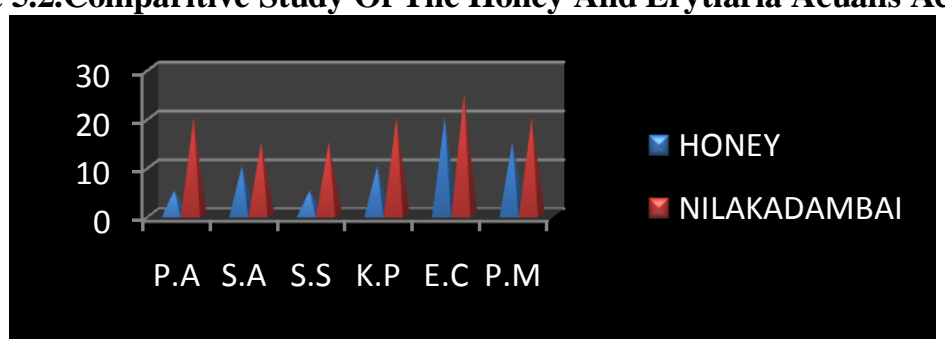

KEY :

P.A $\rightarrow$ Pseudomonas aeruginosa

$\mathrm{S} . \mathrm{A} \rightarrow$ Staphylococcus aureus

$\mathrm{S} . \mathrm{S} \rightarrow \quad$ Staphylococcus saprophyticus

$\mathrm{K} . \mathrm{P} \rightarrow$ Klebsiella pneumonia

E.C $\rightarrow$ Escherichia coli

$\mathrm{P} . \mathrm{M} \rightarrow$ Proteus mirabilis

Plate 5.1.Antibiotic Sensitivity Test

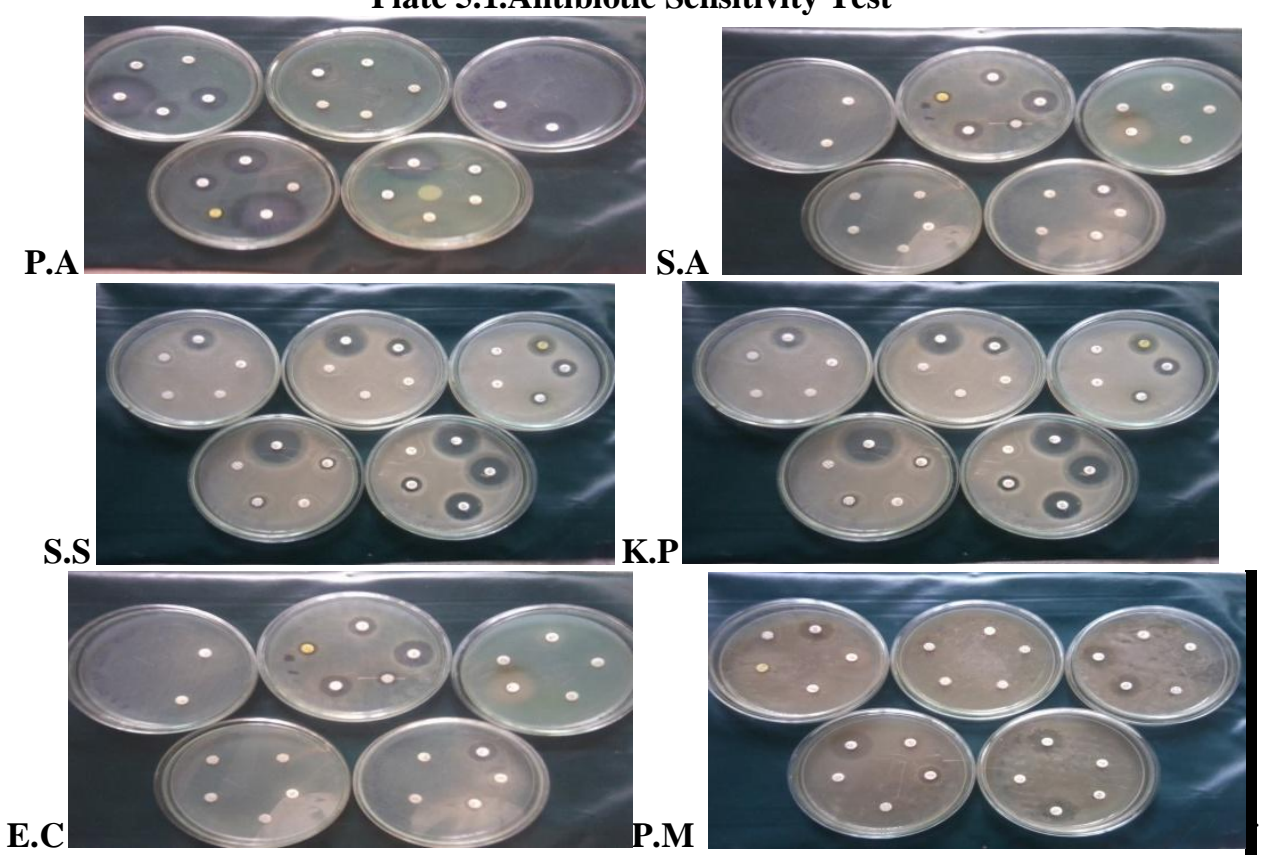

Plate 5.2. Antibacterial Activity Of Honey

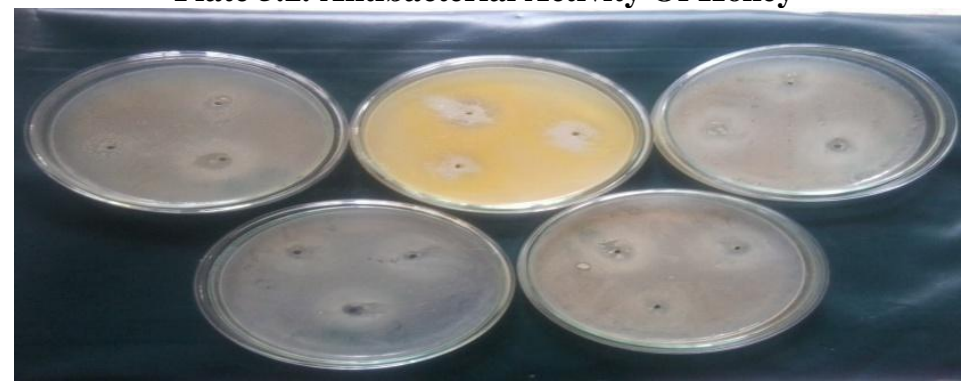

Plate 5.3. Antibacterial Activity Of Erytlaria Acualis Lindau

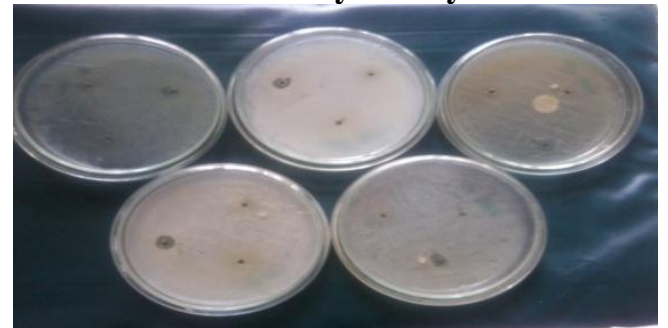

www.iosrjournals.org 


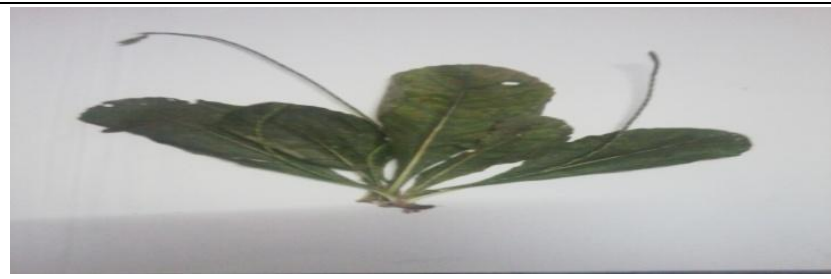

\section{Discussion}

The burnt wound samples were collected and series of tests were performed to detect the specific pathogen present in each one of them. From 50 wound samples 20 was negative and 30 was positive. From 30 samples 11 strains of Pseudomonas aeruginosa, 8 strains of Staphylococcus aureus , 1strain of Staphylococcus saprophyticus, 2 strains of Klebsiella pneumonia, 5 strains of Escherichia coli, 3 strains of Proteus mirabilis were isolated and their sensitivity or resistant pattern were determined and recorded using honey and Erytlaria acualis.

The organism isolated in the present study showed a slight variation compared with those of the earlier study.This might be due to changing trends in the frequency pattern of the organisms isolated from burnt wound in hospital

During the period from 2006 to 2010 Pseudomonas species was the commonest pathogen isolated (51.5\%) followed by Acinetobacter species (14.28\%), Staphylococcus aureus (11.15\%), Klebsiella species (9.23\%) and Proteus species (2.3\%). When compared with the results of the previous five years i.e., 2006 to 2011, Pseudomonas species was still the commonest pathogen in the burns unit (chart 5.1) However, the isolation of this organism and other gram-negative organisms had decreased in comparison to previous years.

All the strains of Pseudomonas aeruginosa was found to be resistant to ampicillin, clindamycin and tetracyclin. All the five strains of E.coli were ampicillin resistant. Coagulase negative Staphylococci was resistant to various antibiotics like ampicillin, amoxycillin, cefazolin, methicillin, Norfloxacin and penicillin. Strains of Proteus mirabilis was found to be resistant to ampicillin amoxicillin, clindamycin cefazolin, penicillin and tetracyclin and Klebsiella pneumonia was found to be resistant to ampicillin, amoxycillin, clindamycin and vancomycin (Table 5.4). Some strains of Pseudomonas aeruginosa, Staphylococcus aureus and E.coli was found to be Multidrug resistant (Table 5.4)

The concentrated honey was diluted in the ratio of 1:2,1:3, and crude : solvent ratio 1:2 showed antibacterial activity against E.coli, Proteus mirabilis, and some strains of Pseudomonas aeruginosa (Table 5.5.) Honey acts as a highly viscous barrier preventing bacterial penetration and colonization of the wound surface.

The leaf extract of Erytlaria acualis was prepared in three different solvents like distilled water, methanol and ethanol at the ratio of solid : ethanol solvent ratio 1:5 showed antibacterial activity against multi drug resistant Pseudomonas aeruginosa, Methicillin resistant Staphylococcus aureus and also other organisms. (Table 5.6)

\section{Summary}

- 50 burnt wound samples were collected from the patients in the burnt units.

- The various pathogenic organisms were isolated from each of the samples

- The pathogens were identified by performing various general and specific tests for identification.

- Antibiotic sensitivity testing was done using 20 different types of antibiotics.

- Antibacterial sensitivity testing was done using honey and nilakadambai.

- The resistance and sensitivity pattern of the various pathogenic organisms were interpreted.

- A comparative study of the effect of honey and nilakadambai extract was made.

- Nilakadambai was found to be more effective as compared to honey at 1:2 dilution.

\section{Conclusion}

The growing demand and popularity of medicinal plants in rural as well as urban communities (Matsiliza \& Barker, 2001) has placed many medicinal plants under the threat of extinction. Therapeutic use of medicinal plants is an alternative health care option for those living in urban communities, but the only means of healing for some people in rural communities.

In rural communities the therapeutic use of medicinal plants are mainly governed by economic factors, ease of availability and the strong belief in the plant remedies. The use of medicinal plants for treating various ailments ranging from acute to chronic conditions has become a way of life for many indigenous people in rural communities. Based on regular usage, many indigenous people are familiar with the different uses, preparations and identification of medicinal plants. Traditional herbalists and herb-sellers are the main sources of distributing information and prescriptions on medicinal plant remedies in rural communities (Matsiliza \& Barker,2001). 
The growing threat and spread of antibiotic resistance by a wide range of common pathogens has led to increased investigations into traditional medicinal plants as alternatives. Antibiotic resistance are not selective in that antibiotic resistance with the same consequences may affect people living in urban and rural communities around the world. Antibiotics that once readily cured a wide range of infections are becoming less useful mainly due to the misuse of antibiotics and the development of antibiotic resistance

(Nostro et al., 2000).

Although new leads for effective antimicrobials are researched in the plant kingdom, education on the proper use of antimicrobial agents is needed. The development of antibiotic resistance was not anticipated with the development and widespread use of synthetic antibiotics. Therefore it may be wise not to follow the same path with the development of purified medicinal plant extracts used as antibiotics. Herbal remedies prepared from the whole plant are generally safe with fewer side effects if it is used in the proper therapeutic dosages (Hanrahan, 2001). The proper use of standardized herbal extracts and antibiotics that are currently still effective may help in eliminating infections without the development of antimicrobial resistance.

The main aim of the study was to establish the scientific validity of the traditional uses of these plants for treating wound infections. The information regarding the presence or absence of antibacterial activity may enhance the use of efficacious indigenous plant remedies.

The antibacterial activity of the plant extracts against the different clinical strains of burn wound pathogens supported the scientific validity of the plants being used traditionally for treating wounds infected with these bacteria.

Thus it can be concluded that extract of Erytlaria acualis was found to be more effective medication against the wound infection caused by these pathogen including multi drug organisms and methicillin resistant Staphylococcus aureus. Thus Erytlaria acualis was effective than both honey and antibiotics.

\section{Future Scope}

The activity of various antibacterial plants can be tested against wound pathogens. It can also be tested against fungi causing skin infections Erytlaria Acualis is the plant used as the traditional folklore medicine for cattle wounds, has an ability to kill worms and has an efficient healing property. It can also used by the humans for healing wounds, as my grandfather used the extract of Erytlaria acualis (nilakadambai) for his own operated wound in legs.

\section{Appendix}

\subsection{Transport Medium}

\subsubsection{Cary Blair Medium}

Disodium phosphate $\quad-\quad 1.100 \mathrm{~g}$

Sodium thioglycollate $\quad-1.500 \mathrm{~g}$

Sodium chloride $\quad-\quad 5.000 \mathrm{~g}$

Agar

Distilled water $\quad-\quad 1000 \mathrm{ml}$

Final $\mathrm{pH}\left(\right.$ at $\left.25^{\circ} \mathrm{C}\right) \quad-8.4 \pm 0.2$

Suspend 12.6 grams in $991 \mathrm{ml}$ distilled water. Heat to boiling to dissolve the medium completely. Cool to $50^{\circ} \mathrm{C}$ and aseptically add $9 \mathrm{ml}$ of $1 \%$ aqueous calcium chloride solution. Adjust $\mathrm{pH}$ to 8.4 if necessary.

Distribute in $7 \mathrm{ml}$ amounts in screw-capped tubes. Steam for 15 minutes. Cool and tighten the caps.

\subsection{Plating Medium}

9.2.1. Nutrient Agar

Peptic digest of animal tissue

Beef extract

Yeast extract

Sodium chloride

Agar

Distilled water

Final $\mathrm{pH}$

$\begin{array}{lll}- & 5 \mathrm{~g} & \\ & - & 1.5 \mathrm{~g} \\ & - & 1.5 \mathrm{~g} \\ - & 5 \mathrm{~g} & \\ & - & 15 \mathrm{~g} \\ - & 1000 \mathrm{ml} & \\ - & 7.4 & \end{array}$

The nutrient agar was prepared dissolving the components in distilled water, and sterilizing by autoclaving at $121^{\circ} \mathrm{C}$ at 15 psi pressure for 15 mins. The medium was then plated.

\subsubsection{Macconkey Agar}

Peptone

Sodium chloride

Bile salts

Lactose
$20 \mathrm{~g}$

$5 \mathrm{~g}$

- $10 \mathrm{~g}$
$1.5 \mathrm{~g}$

www.iosrjournals.org

16 | Page 


\begin{tabular}{llll}
\hline Sodium taurocholate & - & $5 \mathrm{~g}$ & \\
Crystal violet & & - & $0.001 \mathrm{~g}$ \\
Neutral red & & - & $0.03 \mathrm{~g}$ \\
Agar & & - & $15 \mathrm{~g}$ \\
Distilled water & - & $1000 \mathrm{ml}$ & \\
Final pH & - & 7.4 &
\end{tabular}

The mac conkey agar was prepared dissolving the components in distilled water, and sterilizing by autoclaving at $121^{\circ} \mathrm{C}$ at 15 psi pressure for 15 mins. The medium was then plated.

\subsubsection{Muller Hinton Agar}

Beef infusion extract

Caesin acid hydrolysate

Starch

Agar

Distilled water

Final $\mathrm{pH}$

The medium was prepared dissolving the components in distilled water, and sterilizing by autoclaving at $121^{\circ} \mathrm{C}$ at 15 psi pressure for 15 mins. The medium was then plated.

\subsection{Gram Staining Reagents}

\section{SOLUTION A}

Crystal violet

Ethyl alcohol 95\%

$\begin{array}{lll}- & 300 \mathrm{~g} & \\ - & 17.5 \mathrm{~g} & \\ & - & 1.5 \mathrm{~g} \\ & - & 17 \mathrm{~g} \\ - & 1000 \mathrm{ml} & \end{array}$

SOLUTION B

Ammoium oxalate

Distilled water

Solution A\&B is mixed

GRAMS IODINE

Iodine

Potassium

Distilled water

GRAM'S DECOLOURIZER

Iodine

Potassium iodine

Methanol

Acetone

SAFRANIN,0.5\% W/V

Safranin

Ethyl alcohol,95\%

$$
\begin{array}{ll}
- & 2 \mathrm{~g} \\
- & 20 \mathrm{ml} \\
& \\
\hline 80 \mathrm{ml} & 0.8 \mathrm{~g}
\end{array}
$$

$\begin{array}{ll}- & 1 \mathrm{~g} \\ - & 2 \mathrm{~g} \\ 300 \mathrm{ml} & \end{array}$

$1 \mathrm{~g}$
$2 \mathrm{~g}$

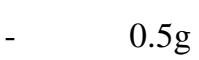

$0.3 \mathrm{~g}$

$120 \mathrm{ml}$

$4.5 \mathrm{ml}$

$2.5 \mathrm{~g}$

$100 \mathrm{ml}$

9.4. Media For Biochemical Test

9.4.1. Peptone Water

Peptone

$10 \mathrm{~g}$

Sodium chloride - $\quad 5 \mathrm{~g}$

Distilled water - $\quad 1000 \mathrm{ml}$

Final $\mathrm{pH}$

7.6

The was prepared by dissolving the components in distilled water dispensed in test tubes and sterilized by autoclaving at $121^{\circ} \mathrm{C}$ at 15 psi pressure for 15 mins.

\subsubsection{Mr-Vp Broth}

$\begin{array}{llll}\text { Peptones } & & - & 7 \mathrm{~g} \\ \text { Dextrose } & & - & 5 \mathrm{~g} \\ \text { Dipotassium phosphate } & - & 5 \mathrm{~g} & \\ \text { Distilled water } & - & 1000 \mathrm{ml} \\ \text { Final } \mathrm{pH} & - & 6.9 & \end{array}$

The medium was prepared by dissolving the components in distilled water dispensed in test tubes and sterilized by autoclaving at $121^{\circ} \mathrm{C}$ at 15 psi pressure for 15 mins.

\subsubsection{Simmons Citrate Medium}

Magnesium phosphate

$$
-\quad 0.20 \mathrm{~g}
$$




\begin{tabular}{llll}
\hline Ammonium dihydrogen phosphate & $0.20 \mathrm{~g}$ & & \\
Sodium ammonium phosphate & - & $0.80 \mathrm{~g}$ & \\
Dipotassium phosphate & - & $1 \mathrm{~g}$ & \\
Sodium citrate & - & $2 \mathrm{~g}$ & \\
Sodium chloride & - & $5 \mathrm{~g}$ & \\
Bromothymol blue & & - & $0.08 \mathrm{~g}$ \\
Agar & & - & $15 \mathrm{~g}$ \\
Distilled water & - & $1000 \mathrm{ml}$ & \\
Final pH & - & 7.0 &
\end{tabular}

The medium was prepared by dissolving the components in distilled water dispensed in test tubes and sterilized by autoclaving at $121{ }^{\circ} \mathrm{C}$ at 15 psi pressure for 15 mins. The tubes were then placed in a slanting position and allowed to solidify to form agar slopes.

\subsubsection{Triple Sugar Iron Agar}

Peptic digest of animal tissue

Caesin hydrolysate

Yeast extract

Beef extract

Lactose

Sucrose

Dextrose

Sodium chloride

Ferrous sulphate

Ferric citrate

Sodium thiosulphate

Phenol red

Agar

Distilled water

Final $\mathrm{pH}$

$\begin{array}{lll}- & 10 \mathrm{~g} & \\ & - & 10 \mathrm{~g} \\ & - & 3 \mathrm{~g} \\ & - & 3 \mathrm{~g} \\ - & 3 \mathrm{~g} & \\ - & 10 \mathrm{~g} & \\ & - & 1 \mathrm{~g} \\ - & 5 \mathrm{~g} & \\ - & 0.2 \mathrm{~g} & \\ & - & 0.3 \mathrm{~g} \\ - & 0.3 \mathrm{~g} & \\ & - & 0.024 \mathrm{~g} \\ & - & 15 \mathrm{~g} \\ & 1000 \mathrm{ml} \\ - & 7.4 & \end{array}$

The medium was prepared by dissolving the components in distilled water dispensed in test tubes and sterilized by autoclaving at $121{ }^{\circ} \mathrm{C}$ at 15 psi pressure for 15 mins. The tubes were then placed in a slanting position and allowed to solidify to form agar slopes.

\subsubsection{Christens Urea Agar Base}

Peptic digest of animal tissue

Dextrose

Sodium chloride

Disodium phosphate

Monopotassium phosphate

Phenol red

Agar

Distilled water

Final $\mathrm{pH}$

$\begin{array}{lll}- & 1 \mathrm{~g} & \\ & - & 1 \mathrm{~g} \\ - & 5 \mathrm{~g} & \\ - & 1.2 \mathrm{~g} & \\ 0.80 \mathrm{~g} & & \\ & - & 0.012 \mathrm{~g} \\ & - & 15 \mathrm{~g} \\ - & 1000 \mathrm{ml} & \\ - & 6.8 & \end{array}$

The medium was prepared by dissolving the components in distilled water dispensed in test tubes and sterilized by autoclaving at $121{ }^{\circ} \mathrm{C}$ at 15 psi pressure for 15 mins. After cooling to approximately $45-50{ }^{\circ} \mathrm{C}$ $50 \mathrm{ml}$ of $40 \%$ of the urea solution was added and the tubes were then placed in a slanting position and allowed to solidify to form agar slopes.

\subsubsection{Nitrate Broth}

$\begin{array}{llll}\text { Peptone } & - & 5.0 \mathrm{~g} & \\ \text { Meat extract } & & - & 3.0 \mathrm{~g} \\ \text { Potassium nitrate } & - & 1.0 \mathrm{~g} & \\ \text { Distilled water } & - & 1000 \mathrm{ml} & \\ \text { Final pH } & - & 7.0 & \end{array}$

The medium was prepared by dissolving the components in distilled water dispensed in test tubes and sterilized by autoclaving at $121^{\circ} \mathrm{C}$ at 15 psi pressure for 15 mins. 


\section{Bibliography}

[1]. A Bergman, J Yanai, J Weiss.(2001) Acceleration of wound healing by topical application of honey - an animal model. Am J Surg 1983; 145:374-76.

[2]. Alekshun, M \& Levy, S. (2001). The line of least resistance. Economist, 359(8220), pp. $71-72$.

[3]. Andrews, J.M. (2004). Determination of Minimum Inhibitory Concentrations.Department of Microbiology [online]. [Cited June 28, 2004] Available from Internet URL http://jac.oupjournals.org/cgi/reprint/48/suppl_1/5

[4]. Andrews.J., Ashby. J., Jevons. G., Lines. N. \& Wise. R., (1999) Antimicrobial resistance in Gram-positive pathogens isolated in the UK between October 1996 and January 1997. Journal of Antimicrobial Chemotherapy, 43, pp. 689 - 698.

[5]. Arslan, E., Dalay, C., Yavuz, M., Göcenler, L. \& Acarturk, S. (1999). Gram-negative bacterial surveillance in burn patients. Annals of Burns and Fire disasters. 12(2), pp. $1-5$.

[6]. Bagdonas, R., Tamelis, A. \& Rimdeika, R. (2003). Staphylococcus aureus in the surgery of burns. Medicina, 39(11), pp. 10781081 .

[7]. Berkowitz, F.E. (1995). Antibiotic resistance in bacteria. Southern Medical Jourmal, 88, pp. $797-804$.

[8]. Bodeker, G.C. (2001). Traditional health systems and national policy. The Research Council for Complementary Medicine [online] [Cited March 15, 2002] Available from Internet URL http://www.rccm.org.uk/article_gerry_bodeker.htm

[9]. Boswell, A., Andrews, J.M. \& Wise, R. (2001). Comparison of the in vitro activities of four fluoroquinolones against Streptococcus pneumoniae. Journal of Antimicrobial Chemotherapy, 48, pp. $445-458$.

[10]. Bowler, P.G., Deurden, B.I. \& Armstrong, D.G. (2001). Wound microbiology and associated approaches to wound management. Clinical Microbiology Reviews, 14(2), pp. $244-269$.

[11]. Cox, P. A. \& Balick, M.J. (1994). The ethnobotanical approach to drug discovery. Scientific American, pp. 60 - 65.

[12]. Crowley, L.V. (1997). Introduction to human disease. (4th ed.). London : Jones \& Bartlett.

[13]. Damjanov, I. (1996). Pathology for the health related professions. USA : W.B. Saunders.

[14]. Devienne, K. \& Raddi, M.S.G. (2002). Screening for antimicrobial activity of natural products using a microplate photometer. Brazilian Journal of Microbiology, 33, pp.166-168.

[15]. Eloff, J.N. (1998a). Which extractant should be used for the screening and isolation of antimicrobial components from plants? Journal of Ethnopharmacology, 60, pp.1-8.

[16]. Eloff, J.N. (1998b). A sensitive and quick microplate method to determine the minimal inhibitory concentration of plant extracts for bacteria. Planta Media, 64, pp.711-713.

[17]. Eloff, J. (1999). The antibacterial activity of 27 southern African members of the Crombretacae. South African Journal of Science, 95, pp. 148-152.

[18]. Eloff, J. (2000). On expressing the antibacterial activity of plant extracts-a small first step in applying scientific knowledge to rural primary health care. South African Journal of Science, 96(3), pp. $116-118$.

[19]. Ernst, E., (1999). Second thoughts about the safety of St John's wort. The Lancet, 354, pp. $2014-2015$.

[20]. Essawi, T. \& Srour, M. (2000). Screening of some Palestinian medicinal plants for

[21]. antibacterial activity. Journal of Ethnopharmacology, 70, pp. $343-349$.

[22]. Fabry, W., Okemo, P.O. \& Ansorg. (1998). Antibacterial activity of East African medicinal plants. Journal of Ethnopharmacology, 60, pp. $79-84$.

[23]. Gabrielson, J., Hart., M. Jarelöv, A., Kühn, I., McKenzie, D. \& Möllby, R. (2002).

[24]. Evaluation of indicators and the use of digital scanners and spectrophotometers for quantification of microbial growth in microplates. Journal of Microbiological Methods, 50(1), pp. 63 - 73.

[25]. George, J., Laing, M.D. \& Drewes, S.E. (2001). Phytochemical reseach in South Africa. South African Journal of Science, 97(3/4), pp. $93-106$.

[26]. George, J. \& van Staden, J. (2000). Intellectual property rights: plants and phytomedicinals - past history, present scenario and future prospects in South Africa. South African Journal of Science, 96, pp. 433 - 442.

[27]. Greenwood, D., Slack, R.C. \& Peutherer, J.F. (1997). Medical microbiology - A guide to microbial infections : pathogenesis, immunity, laboratory diagnosis and control. (15th ed.). United Kingdom : Churchill Livingstone.

[28]. Grierson, D.S. \& Afolayan, A.J. (1999a). Antibacterial activity of some indigenous plants used in the treatment of wounds in the Eastern Cape, South Arica. Journal of Ethnopharmacology, 66, pp. 103 - 106.

[29]. Grierson, D.S. \& Afolayan, A.J. (1999b). An ethnobotanical study of plants used for the treatment of wounds in the Eastern Cape, South Africa. Journal of Ethnopharmacology, 67, pp. 327-32.

[30]. Hanrahan, C. (2000). Botanical medicine. The Gale Encyclopaedia of Alternative Medicine. Kristine Krapp and Jacqualine L. Longe, Editors. Farmington Hills, Mich.: Gale Group.

[31]. Jones, L. (2002, August 2). Burns are lethal injuries that kill. [Letter to the editor]. The Herald, p. 6.

[32]. Kerr, K.G., Rotowa, N.A., Hawkey, P.M. \& Lacey, R.W. (1990). Evaluation of the Mast ID and API 50CH systems for identification of Listeria spp. Applied and Environmental Microbiology, 56(3), pp 657 - 660.

[33]. Kingsley, A. (2001). A proactive approach to wound infection. Nursing Standard, 15(30), pp. $50-58$.

[34]. Kong, J.M., Goh, N.K., Chia, L.S., Chia, T.F. (2003). Recent advances in traditional plant drugs and orchids. Acta Pharmacologica Sinica, 24(1), pp $7-21$.

[35]. Lin, J., Opoku, A.R., Geheeb-Keller, M., Hutchings, A.D., Terblanche, S.E., Jäger, A.K. \& van Staden, J. (1999). Preliminary screening of some traditional zulu medicinal plants for anti-inflammatory and anti-microbial activities. Journal of Ethnopharmacology, 68, pp. $267-274$.

[38]. Nester, E.W., Anderson, D.G., Roberts, C.E., Pearsall, N.N, \& Nester, M.T. (2004). Microbiology : A human perspective. (4th

[36]. Mangala Bannur, GS Attar, RP Fule. Honey - An useful antimicrobial for superficial wound infections. Indian J Med Microbial 1994; 12(4):244-46.

[37]. M Subrahmanyam. Topical application of honey in treatment of burns. Br J Surg 1978; 78(4):497-98. ed.). New York : McGraw -Hill.

[39]. Nostro, A., Germanò, M.P., D’Angelo, V., Marino, A. \& Cannatelli, M.A. (2000). Extraction methods and bioautography fro evaluaion of medicinal plant antimicrobial activity. Letters in Applied Microliology, 30, pp. 379 - 384.

[40]. Packham, C.L. (1998). Essential of occupational skin management : A practical guide to the creation and maintenance of an effective skin management system. ( $1^{\text {st }}$ ed.). Southport : Limited edition press.

[41]. Palmeiri, T.L. \& Greenhalgh, D.G. (2002). Topical treatment of pediatric patients with burns. Am J Clin Dermatol, 3(8), pp. 529 -34 .

[42]. Pruitt, B.A., Mcmanus, A.T., Kim, S.H. \& Goodwin, C.W. (1998). Burn wound infections : current status. World Journal Surgery, 22(2), pp. 135-145. 
[43]. Rabe, T. \& van Staden, J., (1997). Antibacterial activity of South African plants used for medicinal purposes. Journal of Ethnopharmacology, 56, pp. $81-87$.

[44]. Rodgers, G.L., Mortensen, J., Fisher, M.C., Lo, A., Creswall, A. \& Long, S.S. (2000). Predictors of infectious complication after burn injuries in children. Journal of Pediatric Infectious Diseases, 19(10), pp.990-995.

[45]. Ruschitzka, F., Meier, P.J., Turina, M., Lüscher, T.F. \& Noll, G., (2000). Acute heart transplant rejection due to Saint John's wort rejection. The Lancet, 355 , pp. $548-549$.

[46]. Siegfried, W. R. (1989). Preservation of in southern Africa nature reserves. Biotic Diversity in Southern Africa. Oxford University Press : Cape Town.

[47]. Shale, T.L., Stirk, W.A., and van Staden, J. (1999). Screening of medicinal plants used in Lesotho for anti-bacterial and antiinflammatory activity. Journal of Ethnopharmocology. 67, pp. $347-354$

[48]. Skinner, A.M., Brown, T.L.H., Peat, B.G. \& Muller, M.J. (2004). Reduced hospitalisation of burns patients following a multimedia campaign that increased adequacy of first-aid treatment. Burns, 30, pp. $82-85$.

[49]. Spjut, R.W. (1985). Limitation of a random search : search for new anticancer drugs in higher plants. Econ. Bot. 39 , pp. 266 - 288

[50]. Totora, G.J. \& Grabowski, S.R. (1996). Principles of anatomy and physiology ( $8^{\text {th }}$ ed.). New York : HarperCollins

[51]. Ugburo, A.O., Atoyebi, O.A., Ojenejin, J.O. \& Sowemimo, G.O.A. (2004). An evaluation of the role of systemic antibiotic prophylaxis in the control of burn wound infection at the Lagos University Teaching Hospital. Burns, 30, pp.43 - 48.

[52]. Van Staden, L.F. \& Drewes, S.E. (1994). Knipholone from Bulbine latifolia and Bulbine frutescens. Phytochemistry, 35(3), pp. $685-686$.

[53]. Van Wyk, B-E. \& Gericke, N. (2000). People's plants : A guide to useful plants of Southern Africa (1st ed.). Pretoria : Briza publications.

[54]. Ward, R.S. \& Saffle, J.R. (1995). Topical agents in burn and wound care. Physical Therapy, 75(6), pp. 526 - 538.

[55]. Watt, J.M. \& Breyer - Brandwijk, M.G. (1962). The Medicinal and Poisonous Plants of South Africa (2nd ed.). Livingstone : London.

[56]. Williamson, E., (2003). Drug interactions between herbal and prescription medicines. Drug safety, 26(15), pp. 1075 - 1092 .

[57]. World Conservation Monitoring Centre (1992). Global diversity: status of the Earth's Living resources. Chapman and Hall : London. 